DOI 10.47649/vau.2020.v59.i4.05

МРНТИ 81.09.81

УДК 327(075.8)

\author{
K.Zhumabaeva', M.Sapanova² \\ ${ }^{1}$ Al-Farabi Kazakh National University \\ ${ }^{2}$ Expert, the branch of "Academy of public administration under the President of the Republic of \\ Kazakhstan" in Almaty \\ Almaty, Kazakhstan
}

\title{
SOME ISSUES PERIODIZATION OF CHINA'S FOREIGN POLICY
}

The article deals with some issues of periodization of China's foreign policy, political traditions and modern foreign policy concepts of China in the relations of Central Asian countries.

The authors define the foreign policy priorities of the People's Republic of China from ancient times to the present. Traditionally, China deals with conflicts through informal mechanisms of reconciliation and consent, as close as possible to the form of discussion. The fundamental principles of Confucianism, projected on the system of relations between China and the outside world, "vertical connections" in international relations, which characterized from the highest to the lowest.

Under Mao Zedong, the Chinese leadership developed a foreign policy of independence and self-reliance, aimed at combating foreign interference and hegemony.

Today, China is becoming the center of a dynamically developing region of the Asia-Pacific region. In addition, China has a reliable geopolitical base to play the role of a natural center of attraction for the surrounding countries and peoples, which in addition to the countries of East Asia include South Asian and Central Asian countries.

In the new world order, an ethnic communitycementedthe formation of "Greater China" is understood as economic unity.

Key word: China, Central Asia, foreign policy, political traditions, concept, geopolitics.

In China formed, the foundations of statehood and a certain political tradition have been for a long time. The great Chinese historian SIMA Qian (145-86 BC) in his "History"described its most important categories are. Analyzing the forms of government of the ruling houses that ruled in ancient China in his "History", he speaks of three principles - Zheng, Jing and Wen. as about the established political tradition, according to which "in the Kingdom of Xia, the rule was based on Zheng, inherent in human nature, straightforwardness; in the Kingdom of Yin - on Jing, on the instinct of reverence inherent in man; in the Kingdom of Zhou - on Wen, on culture, ..." $[1]$.

From ancient times to the present, informal mechanisms of reconciliation and consenthandled through conflicts, as close as possible to the form of discussion well known in China. Primarily through ritual relationshipsgovernedsociety, so minimal government intervention was required. The communal harmony that determines order at the immediate level, which also determines and expresses the consensus of the government and the people, society and the state [2].

The fundamental principles of Confucianism, projected on the system of relations between China and the outside world, gave rise to Sino centrism, in international relations - from the highest to the lowestcharacterized "vertical connections". In their creation, Confucian concept of paternalism played the main role, the hierarchy of relations in the family, in the community and in relations between States. This Imperial ideology gradually created a special world order in 
which China and its neighbors coexisted. However, China has never been as powerful as neighboring Mongolia during the time of Genghis Khan. And could not assert power over its neighbors through military aggression being the center of the world order, China ("Middle state») he asserted his power over his neighbors more in the sphere of economy and culture than through military aggression, believing that "influence is more important than power". It should be remembered that China for a long period of history did not feel the need for economic domination over its neighbors (self-sufficiency), rather, neighboring States felt the need for economic ties with China. As you know, Chinese who invented many "engines of progress" like gunpowder, paper, porcelain, silk, and even bureaucracy! It is also important that China, along with India and Iran, is the bearer of a specific cultural and historical idea that goes back centuries [3].

Practically Imperial ideology and the "Greater China" system based on it lasted until the middle of the X1X century, when European invasions destroyed the traditional system of relations with neighbors. Mao Zedong and his associates, who headed China in 1949, tried to present themselves as heirs of an ancient tradition, to identify themselves with the Chinese people and their civilization. This principle and this ideology continued to be decisive in the foreign policy of the PRC. In its relations with neighboring States, China has proved to be the successor of the traditional Imperial course.

On October 1, 1949, in Beijingofficially proclaimedthe establishment of thePeople's Republic of China (PRC). This event was preceded by the second Plenum of the CPC Central Committee (March 1949) and the publication of Mao Zedong's program work "On the democratic dictatorship of the people". In his speech at the Plenum, Mao Zedong formulated his own vision of China's development after the end of the civil war. In his opinion, the immediate transition to socialism in China was a matter of the distant future, and the priority was the "new democracy" as a kind of stage on this path. The main task of the party was to transform China into a strong industrial power, with a decisive role for the working class in society. The party leader indicated that the new China would achieve its goals by relying on the socialist camp, primarily the USSR [4].

In foreign policy, Mao Zedong made a huge contribution to the formation of its foundations and the promotion of attitudes on specific issues. Together with Zhou Inlay and other leaders, he developed a foreign policy of independence and self-reliance aimed at combating foreign interference and hegemony. He advocated the principle of combining patriotism with internationalism, for supporting the movement for national independence and liberation, for peace and for other forms of just struggle against imperialism, as well as old and new colonialism, sought to strengthen friendly contacts and cooperation with the peoples of other countries, and the progress of humanity.

However, since 1958, the nature of China's foreign policy has gradually begun to change. Gradually went on the decline of the Soviet-Chinese relations. From the late 1950s, Mao Zedong led the CCP's determined struggle against the leaders of the CPSU, who, in his opinion, stood on the position of great-power chauvinism and tried to interfere in China's internal Affairs and control its actions. He stressed that in the international arena, China must fight against any manifestations of great-power chauvinism and all forms of hegemonies'.

Thus, both sides began a competition as to which of them is the "true Marxist". In the 1970s, he put forward the strategic idea of "three worlds" and opened up new horizons for China's foreign policy because of the normalization of its relations with the United States and Japan, thereby creating a favorable international environment for China's modernization. This 
made it possible for the Chinese government to normalize diplomatic relations with a number of countries that existed before the "cultural revolution" in 1969-1972, as well as to establish such relations with some others. States (at the end of 1972, the PRC maintained diplomatic relations with 81 States) [5].

After the death of Mao Zedong in 1976, a new era in the history of China began. The "architect of Chinese reforms" Deng Xiaoping actually began to play a major role in the leadership of the country. On his initiative, negotiations on the settlement of relations with the USSR began. Since the mid-1980s, the Chinese leadership has been developing the concept of a multipolar world in which the PRC should take its rightful place as one of the "centers of power" not only in Asia, but also in the world as a whole.

In 1989, President of the People's Republic of China elected Jiang Zemin. Deng Xiaoping saw him as his real successor and gradually handed over all the levers of control of the party and the state to him. The official propaganda of China clearly emphasizes the outstanding role of Mao Zedong as the founder of the PRC, Deng Xiaoping as the main ideologist of economic reforms, and Chinese society during the construction of socialism with "Chinese characteristics"accumulated Jiang Zemin as a faithful successor of all the best. Thus, the socalled "third generation" leadership tandem of Jiang Zemin-Zhu Ron qi came to power.

The thirteen years during which he led the party and the state will undoubtedly remain in the history of the PRC as "a period of tremendous growth in the country's total power, which gave the people the greatest benefits. A period of long-term social stability and cohesion, those years when the state's Affairs were good and the people lived in peace and harmony." The collapse of the USSR and the confusion in the post-Soviet space, removing the threat from the North, allowed China to strengthen its position in the Central Asian region.

Today, China can and is becoming the center of such a dynamically developing region as the Asia-Pacific region. In addition, China has a strong geopolitical base (a vast territory with rich resources and a large population) to play the role of a natural center of attraction for the surrounding countries and peoples, which in addition to the countries of East Asia includes South Asian countries and the newly emerged countries of Central Asia.

In the new world order, as economic unity, cemented by an ethnic community understood the formation of "Greater China". China wants to determine and establish its place on the world stage, ensure the country's security as much as possible, and create favorable conditions for its development, primarily by gaining informal leadership in the Asia-Pacific region. The power of this sphere of influence of Chinese economic interests, as stated in a World Bank report from 1993, in the near future may surpass the economic power of Japan and compare with the American one. Under these conditions, primarily as regionalism and paternalism formulated the traditional principles of China's foreign policy. According to Chinese analysts, regionalism involves reducing "external interference and influence at the regional level", will stimulate the development of multipolarity, and will help meet the challenges of globalization.

In 2000, the well-known Chinese political weekly Liao wan wrote about why Chinese foreign policy should focus on border and neighboring States.

First, on the border areas mainly focused with the article points out that China's interests are. In the economic sphere, China's foreign trade, $56 \%$ of export-import activity, is concentrated in neighboring countries, including $53.6 \%$ in Southeast Asia [6]. In the military field, the security issues of neighboring regions (currently, the risk of unleashing conflicts in Asia is quite high) are also directly related to the security of the PRC. Further, Chinese analysts note that, with the exception of Japan, all other countries in this region belong to developing countries 
(including Russia), so they have a lot in common on the issue of creating a new economic order. Apart from Russia and the Philippines, the cultural tradition of neighboring countries mainly goes back to Buddhism, Confucianism and Islam. They all belong to a non-Western culture. Therefore, the position of these countries and China in such important issues for Western political culture as human rights, state sovereignty, non-interference in the internal Affairs of another state, etc. it has a lot in common.

Chinese researchers put forward the thesis that China's power can help protect Border States. This idea clearly traces the Confucian vertical model of building China's relations with other States, when the ruler must protect his subordinates. In October 2002, a generational change took place again, and the "fourth generation" leadership, led by Hu Jintao and Premier Wen Xiaobo, came to power. The new leadership in domestic politics proclaimed a strategy of "great development of the West". The question of the significance of the Western regions in the history of China raised repeatedly. In addition, this is quite understandable. First, we are talking about regions inhabited mainly by non-Han people. Second, most of them are border areas. Third, each and all of them together are rich in natural resources. Which are so important for the Chinese economy. Finally, according to the list of districts included in the latest concept of the "great development of the West", their area is 6.79 million square meters $\mathrm{km}$, or $70.7 \%$ of the territory of China, and the population living within them today is about 500 million people [7]. All this is a set of factors that creates conditions for ensuring national security, and for obvious reasons, the Chinese leadership could not ignore it.

However, until recently, the problem of the "Western territories" solved specifically mainly by sending Han personnel to them, as well as deploying PLA units and paramilitary formations in them, a vivid example of which is the Xinjiang industrial and construction corps. Of course, in parallel with the entire country, socio-economic transformations took place here, but, as a rule, the "Western territories" lagged significantly both in the pace of their implementation and in the quality of the transformations themselves. The gap in the socioeconomic and cultural development of the "Western territories" and the coastal regions has become particularly obvious in recent years.

The newly adopted concept of the "great development of the West" is unique in its own way. Nevertheless, its uniqueness is not only in the fact that, in contrast to the concepts of "Western development" of previous years, the emphasis is mainly on the economy and social sphere. Its uniqueness lies in the scale of the proposed changes. For the first time, the task is not only to "pull up" the "Western territories" to the average level of development of the country, but also to create such conditions in them. Which would allow them to develop in the future not only without the large-scale support of the center, but also to turn into "support bases" focused on the production of a particular type of product that is significant throughout the country.

It is obvious that the "great development of the West" of China will also have an impact on neighboring States. Moreover, the main question for us is impact will express in and the degree of impact on the security of the Central Asian region in General and the Republic of Kazakhstan in particular.

\section{НЕКОТОРЫЕ ВОПРОСЫ ПЕРИОДИЗАЦИИ ВНЕШНЕЙ ПОЛИТИКИ КНР}

В статье рассматривается некоторые вопросы периодизации внешней политики КНР, политические традиции и современные внешнеполитические концепции Китая в отношениях стран Центральной Азии.

Авторами определенывнешнеполитические приоритеты Китайской Народной Республики с древности до настоящего времени. Традиционно Китай с конфликтами справляются при помощи 
неформальных механизмов примирения и согласия, по возможности приближенных к форме дискуссии. Основополагающие принципы конфуцианства, спроецированные на систему взаимоотношений Китая с внешним миром, породили китаецентризм, для которого характерны «вертикальные связи» в международных отношениях - от высшего к низшему. В формирование основ и выдвижение установок по конкретным вопросам внешней политики китайское руководство при Мао Цзэдуне разрабатывало внешнюю политику независимости и опоры на собственные силы, направленную на борьбу с иностранным вмешательством и гегемонизмом.

Сегодня КНР становится центром динамично развивающегося региона АТР. Кроме того, Китай имеет надёжную геополитическую основу, чтобы играть роль естественного центра притяжения для окружающих стран и народов, куда кроме стран Восточной Азии входят южноазиатские и страны Центральной Азии.

А также в условиях нового миропорядка под становлением «Большого Китая» понимается экономическое единство, скрепленное этнической общностью.

Ключевые слова: Кита, Центральная Азия, внешняя политика, политические традиции, концепция, геополитика.

\section{ҚХР СЫРТҚЫ САЯСАТЫН КЕЗЕНДЕРГЕ БӨЛУДІН КЕЙБІР МӘСЕЛЕЛЕРІ}

Мақалада ҚХР сыртқы саясатының кезеңдерінің кейбір мәселелері, Қытайдың Орталық Азия елдері қатынастарындағы саяси дәстүрлері мен қазіргі заманғы сыртқы саяси тұжырымдамалары қарастырылады.

Авторлар Қытай Халық Республикасының ежелгі дәуірден қазіргі уақытқа дейінгі саяси басымдықтарын анықтай отырып, қытайлық сыртқы саясаттың дәстүрлі әдістеріне, оның ішінде жанжалдарды бейресми келісім мен келісім тетіктерінің көмегімен шешу, келіссөздер формасын сараптайды.

Қытайдың сыртқы әлеммен қарым - қатынас жүйесіне бағытталған саясаты конфуцийизмнің негізгі принциптеріне негізделген. Ол өз кезегінде халықаралық қатынастардағы «вертикалды байланыстарды» сипатталатын Қытайлық центризмін саясатын тудырды.

Мао Цзедун тұсында сыртқы саясаттың басымдылықтары негізінен тәуелсіздік пен өз күштеріне сүйенуге және шетелдік араласуға жол бермеу мен гегемонизмге қарсы күреске бағытталған болатын.

Бүгінде ҚХР қарқынды дамып келе жатқан АТА аймағындағы жетекші мемлекет. Сонымен бірге ҚХР көрші мемлекеттер мен халықтар үшін тартымды геосаяси орталығының рөлін атқаруда. Бұл саясаттың геосаяси негізіне Шығыс және Оңтүстік Азия, сол сияқты Орталық Азия елдері кіреді.

Сондай-ақ, жаңа әлемдік тәртіп жағдайында «үлкен Қытайдың» қалыптасуы этникалық қауымдастықпен бекітілген экономикалық бірлікті білдіреді.

Негізгі сөздер: Қытай, Орталық Азия, сыртқы саясат, саяси дәстүрлер, тұжырымдама, геосаясат.

\section{References}

1 China in world and regional politics: history and modernity - Moscow, 2000, p. 57

2 Khafizova K.Sh. Some issues of international relations in Central Asia in the middle of the XVIII century.// Society and state in China: Theses and reports of the third scientific conference, Moscow, 1972.

3 Khafizova K.Sh. Chinese Diplomacy in Central Asia (XIV-XIX ).- Almaty: Sanat.-1996.

4 Konrad N. I. West and East - Moscow, 1972. p. 34

5 Konrad N. I. West and East - Moscow, 1972. p. 35

6 Chinese political weekly "Liaowan", no. of September 28, 2000

7Chinese political weekly "Liaowan", no. of September 28, 2000

\section{Information about authors:}

Kamchat Zhumabaeva, Kazakh National University. Al-Farabi200 K. Myrzaly street, Almaty, Kazakhstan. +7 (707)5587560. E-mail: zhumabaeva1995@list.ru

Marzhan Sapanova, Academy of public administration under the President of the Republic of Kazakhstan" in Almaty, 200 K. Myrzalystreet, Almaty, Kazakhstan.+7(747) 2081639E-mail:sapanovamarzhan2@gmail.com 